\title{
Environmental changes around the Oligocene/Miocene boundary in the Limagne graben, Massif Central, France
}

\author{
Aurélia Wattinne ${ }^{1, *}$, Christophe Lécuyer ${ }^{2}$, Emmanuelle Vennin $^{3}$, Jean-Jacques Chateauneuf ${ }^{4, a}$ and \\ François Martineau ${ }^{2}$ \\ ${ }^{1}$ Groupe Salins, 92-98 bld Victor Hugo, 92115 Clichy Cedex, France \\ ${ }^{2}$ Laboratoire de Géologie de Lyon, CNRS UMR 5276, Université Claude Bernard Lyon 1 et Institut Universitaire de France, Lyon, \\ France \\ ${ }^{3}$ UMR/CNRS 6282, CNRS, Université de Bourgogne-Franche Comté, 6 boulevard Gabriel, Dijon 21000, France \\ ${ }^{4} 8$ quai du Châtelet, Orléans, France
}

Received: 1 February 2018 / Accepted: 30 November 2018

\begin{abstract}
Continental environments are very sensitive to climatic variations. A unique opportunity to study the climate changes where this stage boundary is well constrained by fossils. Indeed, some localities of the Limagne Graben Basin are so rich in mammal remains that they have become a European reference for mammal biostratigraphy. The dominant sedimentary facies of the lacustrine deposits in the northern part of the Limagne Graben Basin are composed of poorly cemented marls and calcarenites containing various plants and animals remains (e.g. algae, fish bones and teeth, gastropods, ostracods, mammals, birds and reptiles remains) associated with stromatolites. Mammal remains, well described in this area from the literature, were used to constrain the chronostratigraphic context of this lacustrine basin, with refinement thanks to new carbon and oxygen isotope measurements, palynological and sedimentological data. In this work, the available information obtained from a classical paleoecological study has been refined by new carbon and oxygen isotope analyses of carbonates and fish teeth retrieved from the washed sediment residues. The results of this study confirm that the Oligocene/Miocene boundary in Europe was a general period of aridity, associated with a cooler climate, which could be the cause of the decline in mammal paleodiversity observed during this period. The gradual evolution from brackish to fresh waters is indicated by the presence of ostracods and gastropods, and the major development of caddisflies. This period is associated to humid climatic conditions while a gradual increase in temperature took place throughout the second part of the Aquitanian. These environmental changes were driven by strong variations of temperatures and a contrasted seasonality.
\end{abstract}

Keywords: Oligocene/Miocene boundary / Limagne Basin / lacustrine carbonate / biozone / oxygen isotopes / apatite / stromatolite

\begin{abstract}
Résumé - Changements environnementaux survenant à la limite Oligocène/Miocène du bassin des Limagnes (Massif central, France). Les environnements continentaux sont très sensibles aux variations climatiques. Une opportunité unique d'étudier les variations climatiques intervenant autour de la limite oligo-miocène est fournie par le bassin des Limagnes, car cette limite y est bien identifiée par les fossiles. En effet, certaines localités du bassin sont si riches en restes de mammifères qu'elles sont devenues des références pour la biostratigraphie mammalienne européenne. Les différents faciès sédimentaires présents dans les dépôts lacustres de la partie nord du bassin sont peu indurés. Il s'agit de marnes et de calcarénites qui ont livré de nombreux fossiles de plantes et d'animaux (algues, restes de poissons, gastéropodes, ostracodes, mammifères, oiseaux et reptiles), associés à des stromatolites. Les mammifères fossiles ont été utilisés par le passé pour contraindre le contexte chronostratigraphique du bassin lacustre; ces données ont été affinées dans ce travail par une étude palynologique et sédimentologique. Les informations obtenues lors de cette étude paléoécologique classique ont été complétées par l'analyse en isotopes stables des carbonates
\end{abstract}

\footnotetext{
*Corresponding author: awattinne@wanadoo.fr

${ }^{\text {a }}$ Retired from BRGM.
} 
et des dents de poissons issues des lavages de sédiments. La présence d'une période d'aridité probablement à l'échelle de l'Europe à la limite oligo-miocène est confirmée par cette étude. Cette période d'aridité, associée à un climat plus froid, comme l'atteste la présence de pollens spécifiques, est probablement responsable de l'appauvrissement de la diversité mammalienne également observée durant cette période. Puis, le passage du milieu saumâtre à un milieu d'eau douce se met en place, à partir de l'Aquitanien, attesté par la présence d'ostracodes et de gastéropodes et le développement exceptionnel des phryganes (insectes Trichoptères). Ce passage est associé à des conditions climatiques de nouveau plus humides. La température, quant à elle, augmente graduellement dans la seconde partie de l'Aquitanien. Ces changements environnementaux ont eu lieu sous un climat à fortes variations de températures et une saisonnalité contrastée.

Mots clés : limite oligo-miocène / bassin des Limagnes / carbonates lacustres / biozone / isotopes de l'oxygène / apatite / stromatolite

\section{Introduction}

Recent advances made in defining the evolution of global climate during the Cenozoic (Zachos et al., 2001) showed that a warming trend during the Late Oligocene reduced the extent of the Antarctic ice cap. Apart from a few events of glacial stages, the global volume of ice remained low until the Middle Miocene, along with a slight increase in bottom water temperature. One of these glacial events, referred as glacial maximum, occurred at the Oligocene/Miocene boundary as documented by Zachos et al. (2001). The present study focuses on this short-lived event and its consequences, in a region that was particularly sensitive to climate change: the continental environment of the Limagne Graben Basin located in the northern part of the Massif Central in France (Fig. 1). The lacustrine facies of this graben are particularly suitable for performing a detailed paleoclimatic study because of the exceptional density of paleontological remains (especially mammals) that enables a valuable dating of the sedimentary deposits. This manuscript reports on the main results of a multidisciplinary investigation of the "Limagne bourbonnaise" deposits at the Oligocene/Miocene boundary. To reconstruct past climate conditions, palynological, sedimentological and stable isotope analyses $\left(\delta^{13} \mathrm{C}, \delta^{18} \mathrm{O}\right)$ of both carbonates (stromatolites and lacustrine limestone) and phosphates (fish teeth) have been performed.

\section{Geological setting}

The Limagne Graben Basin consists of several N-Strending grabens in the northern part of the Massif Central in France and forms a part of the European Cenozoic Rift System (Maury and Varet, 1980; Ziegler, 1990; Merle et al., 1998; Michon, 2000; Dèzes et al., 2004). The northern part of the basin is known as the "Limagne bourbonnaise", the central part as the "Limagne centrale" or "Grande Limagne", and the southern part as the "Limagne d'Issoire" and "Limagne de Brioude" (Fig. 1). Associated with rapid Oligocene subsidence, this structural heritage greatly influenced the sedimentary infill of the basin, which is as much as $2000 \mathrm{~m}$ thick in the "Limagne centrale" (Grolier and Tchimichkian, 1963; Morange et al., 1971; Gorin, 1975; Donsimoni and Giot, 1977). In the "Limagne bourbonnaise", the older sedimentary deposits are Late Lutetian in the eastern part of the basin and Bartonian in the western part (e.g. Late Eocene in age) (Riveline et al.,
1988). The Rupelian (Early Oligocene) lacustrine sediments were preserved in the "Limagne centrale", "Limagne d'Issoire" and "Limagne bourbonnaise" (Guillot, 1991) and reflect a brackish environment characterized by the presence of gastropods (Potamides lamarckii) and coccoliths locally associated with evaporites.

During the Chattian period (Upper Oligocene), a fluvial supply from the north is observed (Wattinne, 2004). The lake at this time was well developed, as testified by the presence of stromatolites in contact with the basement around the basin edges. Nevertheless, a retreat of the shoreline is indicated at the end of the Chattian by the development of numerous paleosols (for more details see Roche et al., 2018).

During the Aquitanian (Early Miocene), the lacustrine domain was mainly restricted to the northern part of the basin (Limagne bourbonnaise; Fig. 2) with fluvial supplies coming from the east (Wattinne, 2004). The western part is characterized by a narrow basin (Fig. 2) filled with Miocene sediments. It is interpreted as an ancient stream that later migrated eastward (Hugueney et al., 1999) to become the present-day Allier River (Fig. 1). The Aquitanian, marking the last lacustrine episode recorded by the sedimentary deposits filling in the graben, was followed by the development of Burdigalian (Early Miocene) fluviatile systems. These deposits are characterized by marls and sandstones with feldspars and silex (Jung, 1946; Bout et al., 1966; Jeambrun et al., 1973; Giot et al., 1979) then are followed by the Pliocene "sand and clays of the Bourbonnais" formation (Tourenq, 1989).

The overall lacustrine sedimentary record of the Limagne Graben Basin is characterized by an alternation of marls and calcarenites associated with stromatolites showing various morphologies (Donsimoni, 1975; Freytet, 2000; Wattinne et al., 2003) and abundant mammal remains.

Some localities in the Limagne graben are so rich in mammal remains that they became reference levels for the European Standard Mammal Biozonation. For example, the faunal content documented in Coderet is used as the reference to define MP 30 (the last level of the Paleogene, referred to as MP) and in Montaigu-le-Blin to define MN2 (the Neogene referred to as MN; Fig. 3). Other mammal localities record the same associations at the Oligocene/Miocene boundary (Hugueney, 1997).

The general persistence of Late Oligocene lineages and the pattern of change being roughly the same throughout Europe suggests that the faunas of the earliest Miocene derived from an impoverished Oligocene assemblage. That is why the position of the Oligocene/Miocene boundary, in terms of 


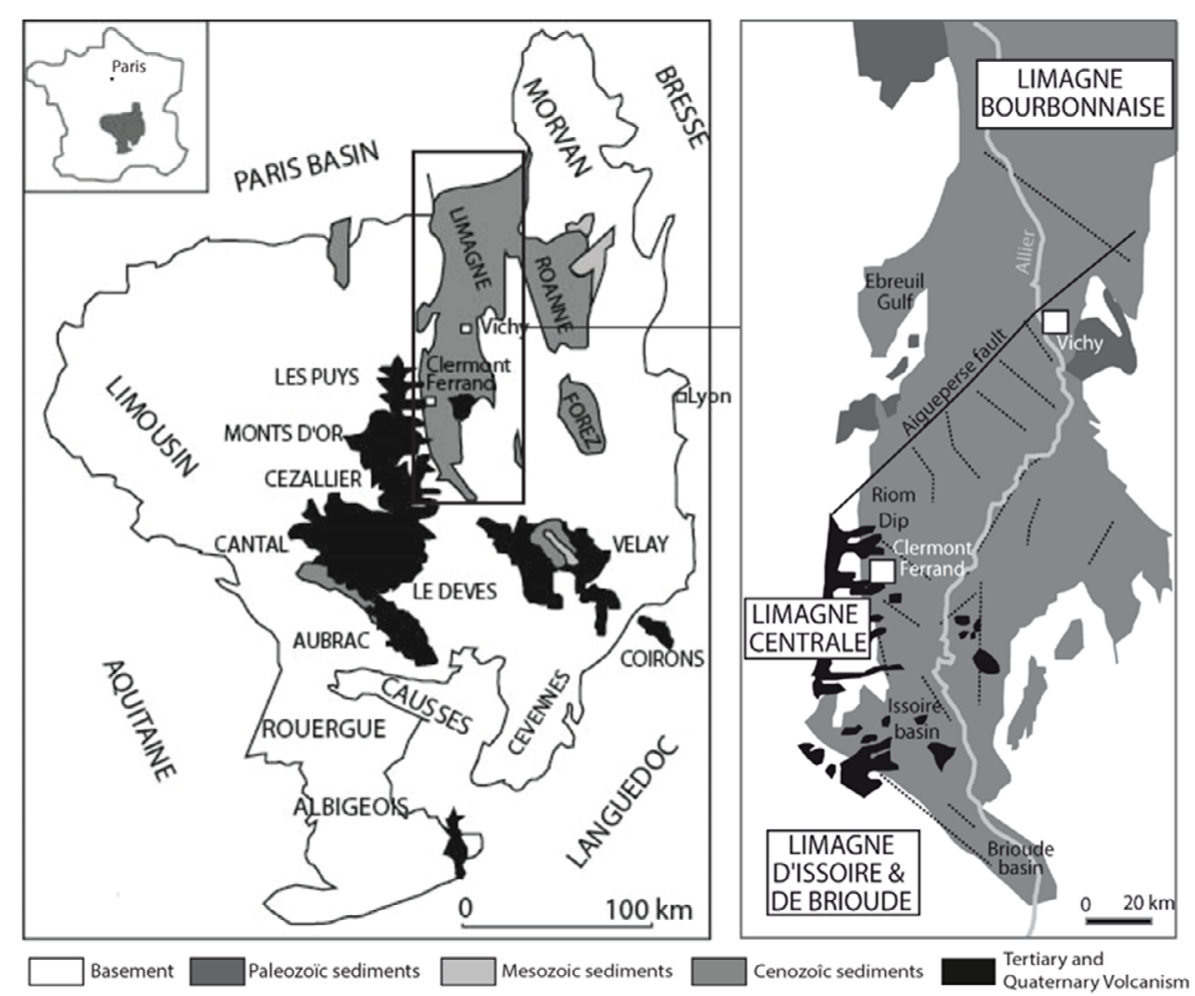

Fig. 1. The Massif Central area, from Roques (1971) and regional sketch map of the Limagne Graben (from COGEMA, in Massoubre, 1986).

mammalian faunas, was debated (Harland et al., 1982; Cavelier and Pomerol, 1983; Odin, 1994; Berggren et al., 1995; Odin et al., 1997; Ginsburg et al., 1998).

The base of the Neogene is fixed at 23.8 Ma (Hugueney et al., 2003) which is also the base of chron C6 Cn.2n (Fig. 3). The Créchy 1-2 level is well correlated with Brochene Fluch 53 (Switzerland) which is estimated as Oligocene by Picot (2002).

These layers are slightly older than Coderet (MP30). The Late Oligocene faunas of Limagne are generally diverse and abundant. The Gannat fauna yielded 13 families and 16 species of which only five are rodents (Fig. 2). The same faunal pattern is recognized in other Limagne localities such as La Roche-Blanche/Gergovie (Hugueney et al., 1999) and Cluzel, and also in Rottenbuch 8 (Germany) (Fahlbusch and Heissig, 1987) and Boudry 2 (Switzerland) (Engesser and Mödden, 1997).

A preliminary overview of the mammal data highlights the location of the Oligocene/Miocene sedimentary boundary in the basin (Fig. 2).

The mammal sites were investigated more specifically in the eastern part of the basin (Créchy, Montaigu-Le-Blin, Gondailly, Chavroches), the Oligocene/Miocene boundary being particularly well exposed at the Créchy site (Hugueney et al., 2003).

\section{Material and methods}

Samples were collected from different quarries (172 samples from Montaigu-le-Blin; 204 samples from Créchy; 13 samples from Gannat). All layers of the studied sections were sampled and systematically washed to identify the coarse components (see Figs. 4, 5A and 5B, for an example of section sampling).

The samples were sieved through $1.0 \mathrm{~mm}, 0.5 \mathrm{~mm}$, $0.250 \mathrm{~mm}, 0.125 \mathrm{~mm}, 63 \mu \mathrm{m}$, and $25 \mu \mathrm{m}$ mesh sizes to remove the finer clay phase and to allow the coarser components to be identified (specifically floral and faunal contents), which were then sorted and counted in a semiquantitative way, with the quantitative abacus proposed by Terry and Chilingar (1955).

Nineteen selected samples were sent to the BRGM laboratory in Orléans, France, to extract the palynomorphs (see Wattinne (2004) for the protocol used). Only four of these samples yielded microflora.

Oxygen isotope ratios of fish tooth phosphate are now considered as reliable low-temperature paleothermometers (Tudge, 1960; Kolodny et al., 1983; Shemesh et al., 1988, Lécuyer et al., 2013). It is widely considered that the oxygen isotope composition of fish teeth provides both water temperature and isotopic composition when the fish was alive and that this record is preserved after death. Oxygen isotope analyses were performed on fossil fish remains sampled from the Créchy and Montaigu-le-Blin quarries. The studied fossiliferous fish beds show a monospecific assemblage of Cyprinidae (Tarsichthys sp. TROSCHEL determined by J. Gaudant). The teeth were isolated through a simple washing of the sediment, then extracted and crushed for isotope analysis. About 30 teeth were pooled per sample, which represents a weight ranging from 15 to $30 \mathrm{mg}$. Sediment layers delivering more than 30 teeth (fossiliferous fish beds) were relatively scarce and were sufficient for only seven analyses (labelled here as layer a to g). Seven additional analyses were performed on teeth collected from contiguous layers (labelled here as 


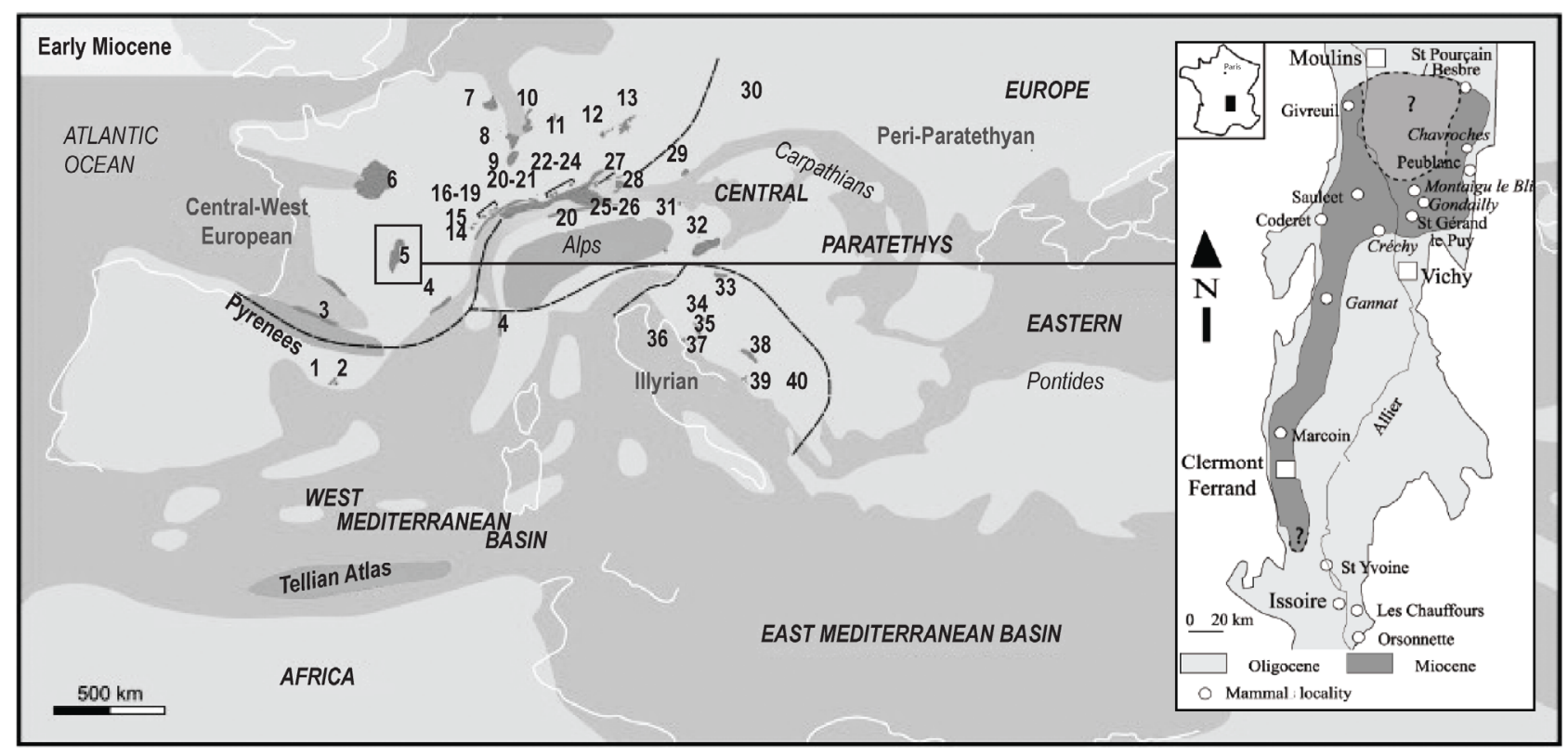

Fig. 2. Palinspastic map for the Early Miocene with indication of palaeobiogeographic units (from Neubauer et al., 2015, modified after Popov et al., 2004 (https://www.sciencedirect.com/science/article/pii/S0012825215000197\#bb0525)). Palaeogeography of the Upper Rhine Graben emended after Berger et al. (2005) (https://www.sciencedirect.com/science/article/pii/S0012825215000197\#bb0065). Outlines are drawn after palaeogeographic reconstructions or sediment distributions. Faunas of freshwater systems fringing the Central Paratethys do not form a homogenous palaeogeographic entity. They are based on too many localities to be clearly indicated on the map. Abbreviations: 1 - Vallès-Penedès (m); 2-Vilanova i la Geltrú (m); 3-Aquitaine (m); 4-Lower Rhône (m); 5-Limagne (1); 6-Paris (m); 7-Lower Rhine (w); 8-Mainz (b); 9-Upper Rhine Graben (b); 10 - Hanau-Wetterau (b); 11 - Rhoen (1); 12 - Sokolov-Cheb (1); 13 - North Bohemian Lake (1); 14 -Sainte-Croix (1); 15 -Fleurier (b); 16 -Courtelary (b); 17 -Moutier (1); 18-Delemont (b); 19-Laufen (1); 20-Upper Marine Molasse (m); 21 -Upper Marine Molasse ("Helicidenmergel") (m); 22 -Öpfingen (1);23 - Thalfingen (w);24 - Oggenhausen (1); 25 - Upper Brackish Water Molasse (b); 26 - Upper Freshwater Molasse (w); 27 - Sandelzhausen (w); 28 - Bavarian Rzehakia (b);29-Moravian Rzehakia (b); 30 - Bełchatów (1); 31 - Korneuburg (f); 32 - Bakony (1); 33 - Mecsek (1);34 - Glina (1);35 - Bihać-Cazin (1);36 - Pag (1); 37-Udbina (1); 38 - Sarajevo (1); 39 - Mostar(1); 40 - Trijebine (1). Environments are characterised as: $\mathrm{b}$-brackish; $\mathrm{f}$-fluviatile; 1 -lacustrine; $\mathrm{m}$-marginal marine; $\mathrm{w}$-wetlands; $\mathrm{u}$ - unknown-Location of the Oligocene/Miocene boundary deduced from mammal sites in the Limagne graben (Hugueney et al., 1999).

\begin{tabular}{|c|c|c|c|c|}
\hline \multicolumn{2}{|c|}{$\begin{array}{l}\text { Magnetostratigraphic } \\
\text { calibration }\end{array}$} & $\begin{array}{c}\text { GERMANY/ SWITZERLAND } \\
\text { /FRANCE (SAVOIE) }\end{array}$ & $\begin{array}{c}\text { Mammal } \\
\text { scale }\end{array}$ & LIMAGNE BASIN \\
\hline \multirow[b]{2}{*}{$\begin{array}{l}\text { uㅡㄹ } \\
\text { 을 }\end{array}$} & \multirow{3}{*}{$23 \mathrm{Ma}$} & La Chaux & MN2a & MONTAIGU-LE-BLIN \\
\hline & & & MN1 & $\begin{array}{l}\text { Upper part of Billy } \\
\text { La Roche Blanche Gergovie } \\
\text { section }\end{array}$ \\
\hline $23,8 \mathrm{Ma}$ & & $\left.\begin{array}{c}\text { Rottenbuch } 8 \\
\text { Boudry } 2\end{array}\right]$ & & $\begin{array}{l}\text { Upper part of the Gannat } \\
\text { section }\end{array}$ \\
\hline \multirow{2}{*}{ 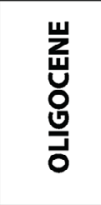 } & \multirow[t]{2}{*}{$24 \mathrm{Ma}^{6 \mathrm{Cn} 2 \mathrm{r}-}$} & $\begin{array}{c}\longleftarrow \text { Brochen Fluch } 53 \\
\text { Küttigen }\end{array}$ & MP30 & $\begin{array}{l}\text { CODERET } \\
\text { Crechy } 1-2 \text { section }\end{array}$ \\
\hline & & $\begin{array}{c}\text { Brochen Fluch 19/20 } \\
\text { Rickenback }\end{array}$ & MP29 & $\begin{array}{l}\text { Lower part of the Crechy } \\
\text { section }\end{array}$ \\
\hline
\end{tabular}

Fig. 3. Mammal localities around the Oligocene-Miocene boundary; the reference localities of the mammal reference scale are in capital letters. Localities calibrated by magnetostratigraphy (bold type) are indicated with their error limits. Brochene Fluch 53 (MP30), is dated from 23.7 to 24.1. Pluridisciplinary analysis of the Brochene Fluch section makes possible the definitive assignment of the Brochene Fluch 53 locality to the Late Oligocene (N.B. in the paper by Becker et al. (2002): the base of the Aquitanian and the corresponding magnetostratigraphy) was erroneously placed in MP 30. It should be placed in level 58 of the section, see Picot (2002). 


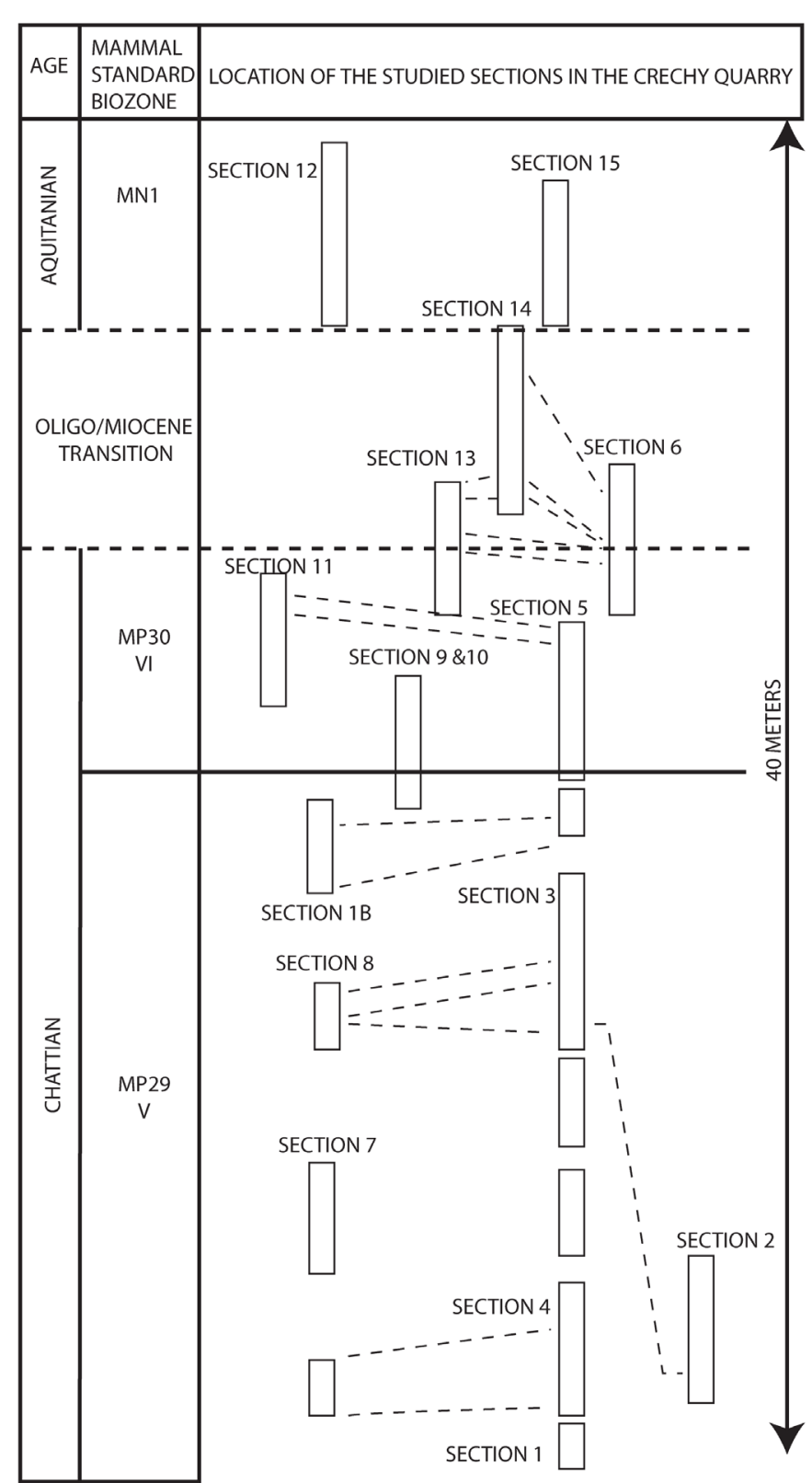

Fig. 4. Location of the studied sections in the Créchy quarry and corresponding biozones.

layers $A$ to $G$ ) that is to say a mixture with teeth coming from different layers but attributed thanks to mammal rests and sedimentological study at the same period of time. This mixture of teeth samples was necessary to obtain the minimum weight required for a high-precision oxygen isotope analysis of the tooth apatite phosphate (Tab. 1). The isolation of phosphate radicals from the fish teeth was performed by precipitating $\mathrm{Ag}_{3} \mathrm{PO}_{4}$ crystals using a method developed by Crowson et al. (1991) and adapted by Lécuyer et al. (1993). The extraction and oxygen isotope analysis followed the method described by O'Neil et al. (1994) and modified by Lécuyer et al. (1998).

For the phosphates, we used the following isotopic fractionation equation (Lécuyer et al., 2013):
$\mathrm{T}\left({ }^{\circ} \mathrm{C}\right)=117.4-4.50\left(\delta^{18} \mathrm{Op}-\delta^{18} \mathrm{Ow}\right) \quad$ with $\quad \delta^{18} \mathrm{Op}=\delta^{18} \mathrm{O}$ value of the phosphate (\%o VSMOW) and $\delta^{18} \mathrm{Ow}=\delta^{18} \mathrm{O}$ value of water (\% VSMOW).

Four samples of lacustrine limestones were selected from the fossiliferous fish beds ( 3 from Créchy, 1 from Montaigu-leBlin) in order to compare their $\delta^{18} \mathrm{O}$ values with those obtained from the fish teeth. The analyses were performed with a Finnigan Delta E isotopic ratio mass spectrometer at the Laboratoire de Géologie de Lyon.

Thin sections for petrographic analyses were made on 10 stromatolite samples and studied under optical transmitted light and cathodoluminescence; the latter technique revealed the internal structure of the stromatolite and locally the presence of diagenetic alteration. In addition, 42 laminations of a stromatolite from Créchy (10 cm high; CRE-1) were sampled with a microdrill core system in order to characterize the isotopic variations recorded during its growth.

Finally, five selected stromatolites (around $10 \mathrm{~cm}$ high) from Créchy, Gannat, Chavroches and Montaigu-le-Blin were powdered and analysed in bulk in order to characterize the global isotopic variations recorded in their structure through the Chattian/Aquitanian boundary.

For the carbonates we used (Anderson and Arthur, 1983) isotopic fractionation equation:

$\mathrm{T}^{\circ} \mathrm{C}=16.9-4.2\left(\delta^{18}\right.$ Ocalcite $-\delta^{18}$ Owater $)+0.13$

$\left(\delta^{18}\right.$ Ocalcite $-\delta^{18}$ Owater) (PDB).

The VSMOW/PDB transition can be calculated from the Coplen et al. (1983) equation:

$\delta^{18} \mathrm{O}(\mathrm{PDB})=0.97002 \times \delta^{18} \mathrm{O}(\mathrm{SMOW})-29.98$.

The use of these equations requires an estimate of the water $\delta^{18} \mathrm{O}$ value, which can be obtained using the Bowen and Wilkinson (2002) equation:

$\delta{ }^{18} \mathrm{O}(\mathrm{VSMOW})$ of the lake water $=-0.0051 \mathrm{Lat}^{2}+0.1805$ Lat-0.002 Alt-5.247,

Lat $=$ latitude of the studied site;

Alt $=$ altitude of the studied site.

\section{Pollen microflora around the Oligocene/ Miocene boundary}

\subsection{Pollen data in Limagne compared with adjacent area}

A set of 20 samples was selected from the open quarries of the Limagne basin for palynological analysis. Most of them were barren of microflora. Nevertheless, four samples from Créchy-Bas (MP29) and Montaigu-le-Blin (MN2a) quarries yielded spores and pollen grains (Tab. 2).

The vegetal communities were mainly composed of coniferal forest elements (including Tsuga, Abies and Picea taxa) and subsequently of deciduous forest taxa represented by Betulaceae, Ulmaceae, Corylaceae, Fagaceae, Juglandaceae, Oleaeceae families. Mega-mesotherms specimens are poorly represented. Nevertheless, the discrepancies highlighted elsewhere between the Chattian and Aquitanian floras (Hochuli, 1979, 1984; Guinet, 1984; Chateauneuf and Nury 1995) also exist in the studied area. The disappearance of Tsuga pollen is observed in the upper part of the Chattian sequence and an increase of Euphorbiaceae-Juglandaceae is pinpointed at the base of Aquitanian. 


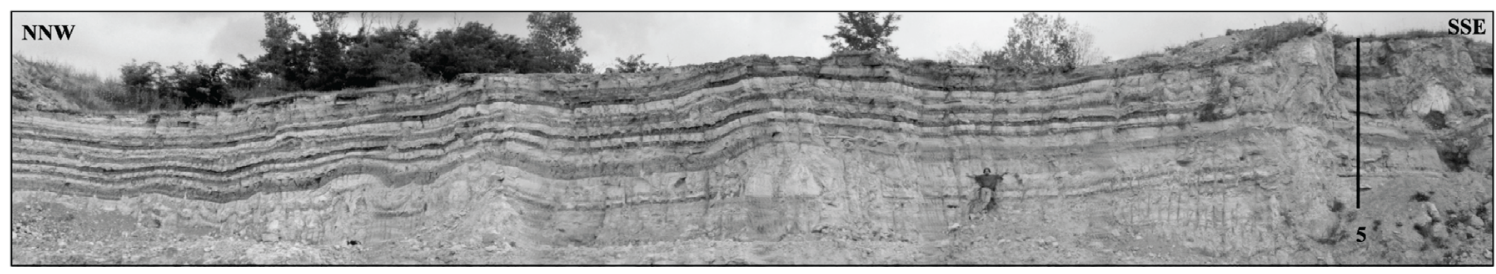

Schema showing the lateral geometry and the morphology of stromatlites".

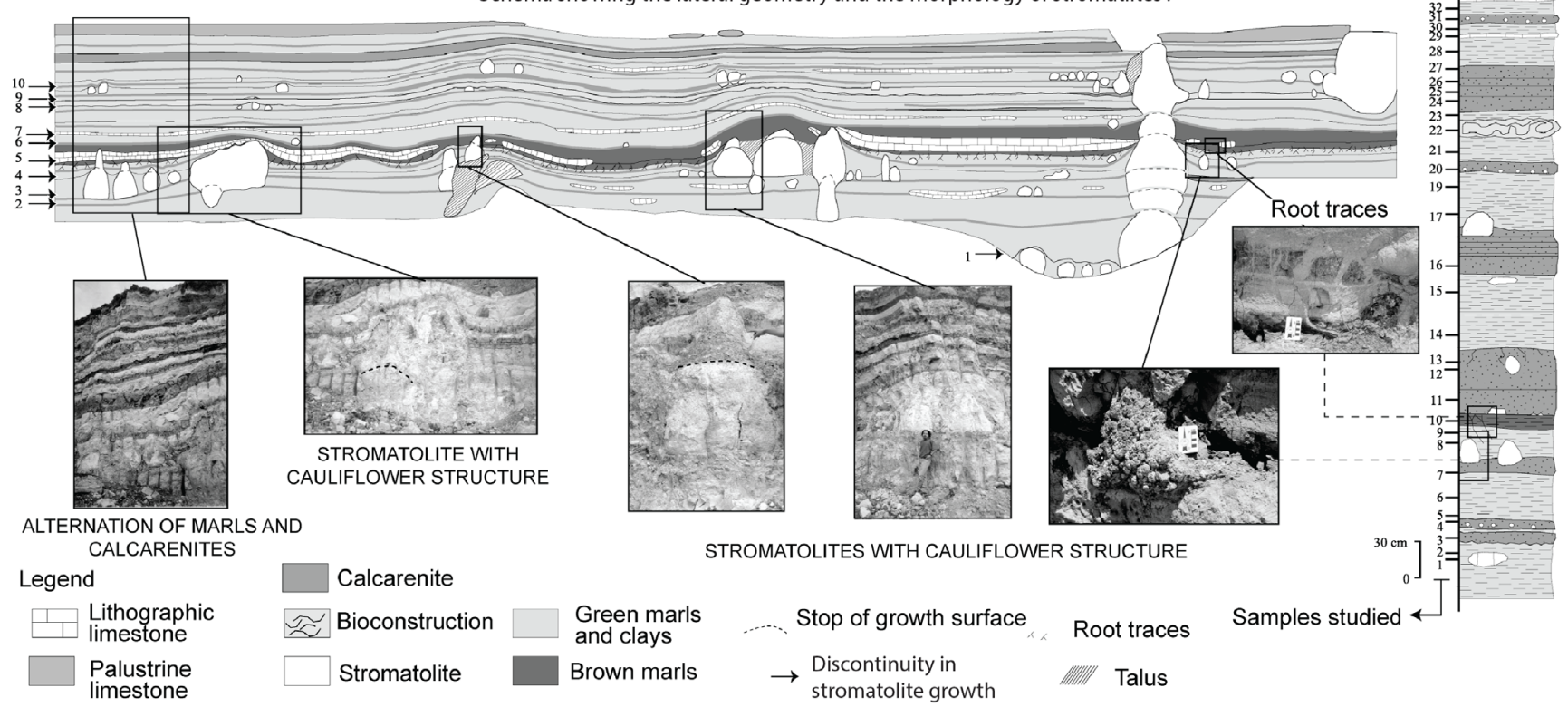

Fig. 5. A. Example of the sedimentological context of the Créchy quarry; detail of Section 5 and sampled layers. B. Example of the different coarse components (\%vol. of the residues) present in the washed sediments of Section 5 (see Figs. 4 and 6 for location) in the Créchy quarry.

Correlations of corresponding associations with the Monbrison basin (Schuler and Sittler, 1969, 1976; Gorin, 1975) or the Provence basin (Bessedik, 1985; Chateauneuf and Nury, 1995) are difficult, due to scarcity and discontinuity of sampling in the Limagne basin area. However, the Créchy-Bas microflora, well dated by mammals (MP29), can be compared with the Provence basins. In the Provence basin, the microflora content at the Chattian-Aquitanian transition has been well documented: a cool dry phase took place during the upper part of the Chattian, but the following Aquitanian climatic changes still need to be better defined (Bessedik, 1985; Chateauneuf and Nury 1995; Nury, 1988; Nury et al., 2016), (Bessedik, 1985, Hugueney and Truc, 1976; Hugueney et al., 1999; Escarguel and Aguilar, 1997; Neubauer et al., 2015).

\section{Sedimentology and associated faunal content}

Sections in the Créchy, Montaigu-le-Blin, Gannat and Gondailly quarries were studied in detail for facies analysis. Four major depositional environments have been proposed (Wattinne, 2004):

- a fluvial domain, characterized by channels infilled by quartz and calcarenite pebbles, conglomerates and sands composed of quartz and locally heavy minerals;
- a proximal lacustrine domain characterized by noncemented calcarenites composed of oncolites, oolites, ostracods, gastropods, fish remains, algal debris and caddisflies, all of them being deposited in a shallow-water environment favourable to stromatolite growth;

- a deeper eutrophic lacustrine zone characterized by wackestones, micropackstones, green marls, and bioaccumulations of ostracods or gastropods;

- a palustrine zone, leading sometimes to protosols with root traces and mudcracks, associated with terrestrial fauna (birds bones, eggshell fragments, mammal remains).

Several repetitive centimetric sequences characterized by alternations of stromatolite-bearing calcarenites and clayey layers have been observed. Most of the clayey layers were halting the growth of the underlying stromatolites. The clayey layers deposits are interpreted as changes in the climatic conditions, with a more arid climate leading to eutrophic conditions.

The Oligocene and Miocene sedimentary deposits contain lacustrine faunal and floral associations which vary in terms of relative abundance around the Oligocene/Miocene boundary. The main faunal and floral assemblages have already been described in the Créchy quarry (Hugueney et al., 2003).

The Oligocene deposits (calcarenites and marls) are dominated by ostracods (Créchy, Gannat) with rare gastropods 
B

\begin{tabular}{|c|c|c|c|c|c|c|c|c|c|c|c|c|}
\hline \multirow[b]{3}{*}{ Sample } & \multirow[b]{3}{*}{ Facies } & \multicolumn{11}{|c|}{$\%$ of residues } \\
\hline & & \multirow[b]{2}{*}{ 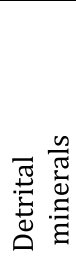 } & \multirow[b]{2}{*}{ 总 } & \multicolumn{3}{|c|}{ Faunal rests } & \multirow[b]{2}{*}{ 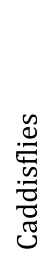 } & \multicolumn{3}{|c|}{ Gastropods } & \multirow[b]{2}{*}{ 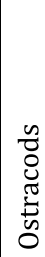 } & \multirow[b]{2}{*}{$\begin{array}{l}\frac{n}{2} \\
\frac{0}{0} \\
\frac{0}{0} \\
\frac{\pi}{2} \\
\frac{\pi}{2}\end{array}$} \\
\hline & & & & b & $\frac{\bar{n}}{\dot{n}}$ & $\begin{array}{l}\mathscr{d} \\
\tilde{D} \\
\varnothing\end{array}$ & & $\frac{\pi}{\frac{\pi}{\pi}}$ & 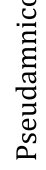 & 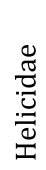 & & \\
\hline 40 & Clayey calcarenite & 8 & 42 & 0 & 14 & 0 & 0 & 0 & 14 & 0 & 14 & 8 \\
\hline 39 & Clayey calcarenite & 8 & 60 & 6 & 8 & 3 & 0 & 0 & 3 & 0 & 9 & 3 \\
\hline 38 & Green marl & 8 & 65 & 0 & 13 & 0 & 0 & 0 & 3 & 0 & 8 & 3 \\
\hline 37 & Fine calcarenite & 11 & 57 & 0 & 14 & 0 & 0 & 0 & 15 & 0 & 3 & 0 \\
\hline 36 & Green marl & 12 & 52 & 0 & 12 & 0 & 0 & 0 & 2 & 0 & 19 & 3 \\
\hline 35 & Brown marl & 8 & 54 & 0 & 38 & 0 & 0 & 0 & 0 & 0 & 0 & 0 \\
\hline 34 & Green marl & 8 & 70 & 0 & 10 & 0 & 0 & 0 & 0 & 0 & 12 & 0 \\
\hline 32 & Green marl & 15 & 60 & 0 & 5 & 0 & 0 & 0 & 5 & 0 & 5 & 13 \\
\hline 31 & Coarse calcarenite & 6 & 60 & 0 & 15 & 0 & 0 & 0 & 8 & 0 & 4 & 7 \\
\hline 30 & Green marl & 8 & 70 & 0 & 0 & 0 & 0 & 0 & 0 & 0 & 10 & 13 \\
\hline 29 & Beige marl & 8 & 82 & 0 & 0 & 0 & 0 & 0 & 0 & 0 & 5 & 5 \\
\hline 28 & Green marl & 8 & 67 & 0 & 24 & 0 & 0 & 0 & 0 & 0 & 1 & 0 \\
\hline 27 & Fine calcarenite & 9 & 58 & 0 & 15 & 0 & 0 & 0 & 10 & 0 & 3 & 5 \\
\hline 26 & Coarse calcarenite & 12 & 53 & 0 & 1 & 0 & 0 & 0 & 8 & 0 & 10 & 16 \\
\hline 25 & Bioclastic calcarenite & 15 & 53 & 2 & 0 & 0 & 0 & 0 & 12 & 0 & 9 & 9 \\
\hline 24 & Bioclastic calcarenite & 8 & 74 & 0 & 0 & 2 & 0 & 0 & 4 & 0 & 0 & 10 \\
\hline 23 & Green marl & 4 & 77 & 0 & 0 & 0 & 0 & 0 & 0 & 0 & 3 & 16 \\
\hline 21 & Brown marl & 8 & 59 & 0 & 25 & 0 & 0 & 0 & 0 & 0 & 0 & 8 \\
\hline 20 & Clayey calcarenite & 8 & 80 & 0 & 8 & 0 & 0 & 0 & 2 & 0 & 2 & 0 \\
\hline 19 & Green marl & 10 & 72 & 0 & 8 & 0 & 0 & 0 & 0 & 0 & 5 & 5 \\
\hline 17 & Green marl & 8 & 63 & 0 & 27 & 0 & 0 & 0 & 2 & 0 & 0 & 0 \\
\hline 14 & Green marl & 15 & 55 & 0 & 30 & 0 & 0 & 0 & 0 & 0 & 0 & 0 \\
\hline 12 & Clayey calcarenite & 4 & 45 & 0 & 12 & 0 & 3 & 0 & 16 & 0 & 8 & 12 \\
\hline 11 & Brown marl & 10 & 70 & 0 & 0 & 1 & 1 & 0 & 0 & 0 & 3 & 15 \\
\hline 10 & Brown marl & 17 & 56 & 0 & 0 & 0 & 0 & 0 & 0 & 0 & 25 & 2 \\
\hline 8 & Green marl & 5 & 62 & 0 & 8 & 0 & 0 & 0 & 0 & 0 & 20 & 5 \\
\hline 7 & Calcarenite & 18 & 40 & 0 & 0 & 0 & 5 & 0 & 19 & 0 & 13 & 5 \\
\hline 6 & Green marl & 5 & 12 & 0 & 0 & 0 & 0 & 0 & 0 & 0 & 81 & 2 \\
\hline 5 & Green marl & 7 & 8 & 0 & 85 & 0 & 0 & 0 & 0 & 0 & 0 & 0 \\
\hline 4 & Fine calcarenite & 8 & 82 & 0 & 0 & 0 & 0 & 0 & 0 & 0 & 5 & 5 \\
\hline 3 & Calcarenite & 5 & 72 & 0 & 5 & 0 & 0 & 0 & 3 & 0 & 5 & 10 \\
\hline 2 & Brown/green marl & 6 & 61 & 0 & 15 & 0 & 0 & 0 & 2 & 0 & 8 & 8 \\
\hline
\end{tabular}

Fig. 5. (Suite)

Table 1. Location and corresponding biozones of the three types of samples selected for the stable isotope analysis.

\begin{tabular}{|c|c|c|c|c|}
\hline Age & Biozone & \multicolumn{3}{|c|}{ Type of sample } \\
\hline Aquitanian & MN2a & $\begin{array}{l}\mathrm{H}-\text { Montaigu-le-Blin } \\
\mathrm{G}-\text { Montaigu-le-Blin }\end{array}$ & (4)-MLB & $\begin{array}{l}\text { Montaigu-le-Blin (MLB) } \\
\text { Chavroches (CHA) }\end{array}$ \\
\hline Oligocene/Miocene boundary & MP30/MN1 & $\begin{array}{l}\text { F-Créchy } \\
\text { f-Créchy }\end{array}$ & (3)-CRE & Créchy (CRE 3) \\
\hline & MP29 V & & & Créchy (CRE 1) \\
\hline
\end{tabular}


Table 2. Number of spore and pollen grains identified in the samples of the Créchy and Montaigu-le-Blin quarries.

\begin{tabular}{|c|c|c|c|c|}
\hline $\begin{array}{l}\text { Localisation } \\
\text { Samples }\end{array}$ & \multicolumn{2}{|c|}{ Crechy route } & \multicolumn{2}{|c|}{ Montaigu-le-Blin } \\
\hline Pinaceae (Pinus diploxylon type) & 40 & 75 & 80 & 80 \\
\hline Pinaceae ( G. Cathaya) & 5 & 5 & $\mathrm{X}$ & 10 \\
\hline Pinaceae (G. Abies) & 8 & 2 & $\mathrm{X}$ & \\
\hline Pinaceae (G. Picea) & 1 & $\mathrm{X}$ & $\mathrm{X}$ & 2 \\
\hline Podocarpaceae (Podocarpus) & 1 & & & 2 \\
\hline Ulmaceae (Ulmus/Zelkova) & 2 & & $\mathrm{X}$ & \\
\hline Betulaceae (G. Alnus) & 1 & & & \\
\hline Betulaceae (G. indeterminé) & 3 & $\mathrm{X}$ & $\mathrm{X}$ & \\
\hline Corylaceae (G.Corylus) & $X$ & & & \\
\hline Fagaceae (G. Quercus) & & & 2 & \\
\hline Juglandaceae (G.Pterocarya/Platycaria) & $\mathrm{X}$ & & & \\
\hline Juglandaceae (other genus) & $\mathrm{X}$ & $\mathrm{X}$ & 2 & \\
\hline Cupressaceae / Taxodiaceae & 2 & 2 & $\mathrm{X}$ & \\
\hline Caprifoliaceae & & & & $\mathrm{X}$ \\
\hline Oleaceae & 1 & 2 & & \\
\hline Ericaceae & $\mathrm{X}$ & & $\mathrm{X}$ & \\
\hline Chenopodiaceae & & $\mathrm{X}$ & $\mathrm{X}$ & \\
\hline Graminae & 5 & & & \\
\hline Ephedraceae (G. Ephedra) & $\mathrm{X}$ & & & \\
\hline Olacaceae & $\mathrm{X}$ & $\mathrm{X}$ & $\mathrm{X}$ & \\
\hline Cycadaceae & & 5 & & \\
\hline Eleagnaceae (Slow. Hippophaeoides) & & $\mathrm{X}$ & & \\
\hline
\end{tabular}

(Bithinella arvernensis BOUILLET = Pseudamnicola arvernensis REY) indicative of a fresh-water environment. The abundance of fish remains at the end of Oligocene is interpreted as successive thanatocœnoses formed during dry periods (Hugueney et al., 2003). Moreover, at the end of the Oligocene, a major development of palustrine facies leading to protosols has been observed. Root traces, mudcracks and fossil bird remains indicate a retreat of the shoreline. Associated faunal content show specific gastropods (Hydrobia sp.), which are indicative of a brackish water environment at Créchy (P. Lozouet, pers.com.), (Fig. 6).

The Miocene deposits (MN1, MN2) are mostly characterized by calcarenites associated with stromatolites, caddisflies, gastropods and ostracods (Fig. 6). The most abundant lacustrine gastropods are Valvata sp. and Pseudamnicola arvernensis, which are usually found in a fresh-water environment (Créchy, Montaigu-le-Blin, Gondailly). All these variations in fauna content are interpreted as resulting from salinity variations in response to a drier event at the Oligocene/Miocene boundary.
The shallow-water lacustrine environment was very sensitive to climate changes and the alternance of palustrine and lacustrine facies through time is interpreted as reflecting changes in the paleo-lake levels that may be linked to rainfall fluctuations associated with a marked seasonality.

\section{Stable oxygen isotope analysis}

\subsection{Stable isotope analysis of bulk stromatolites}

The stromatolites located in the calcarenite levels grew preferentially during wet periods (Wattinne et al., 2003). The data (Tab. 3) show that Aquitanian stromatolites have higher $\delta^{18} \mathrm{O}$ values $(-0.4 ;-0.1)$ than Chattian stromatolites $(-2.9$ to -1.6). Mammal remains (Hugueney, pers com) indicate that Chavroches deposits are older than the Montaigu-le-Blin ones despite their belonging to the same biozones. At the same time, the Chattian stromatolites have negative to slightly positive $\delta^{13} \mathrm{C}$ values $(-3.2$ to 1.5$)$ whereas Aquitanian stromatolites 


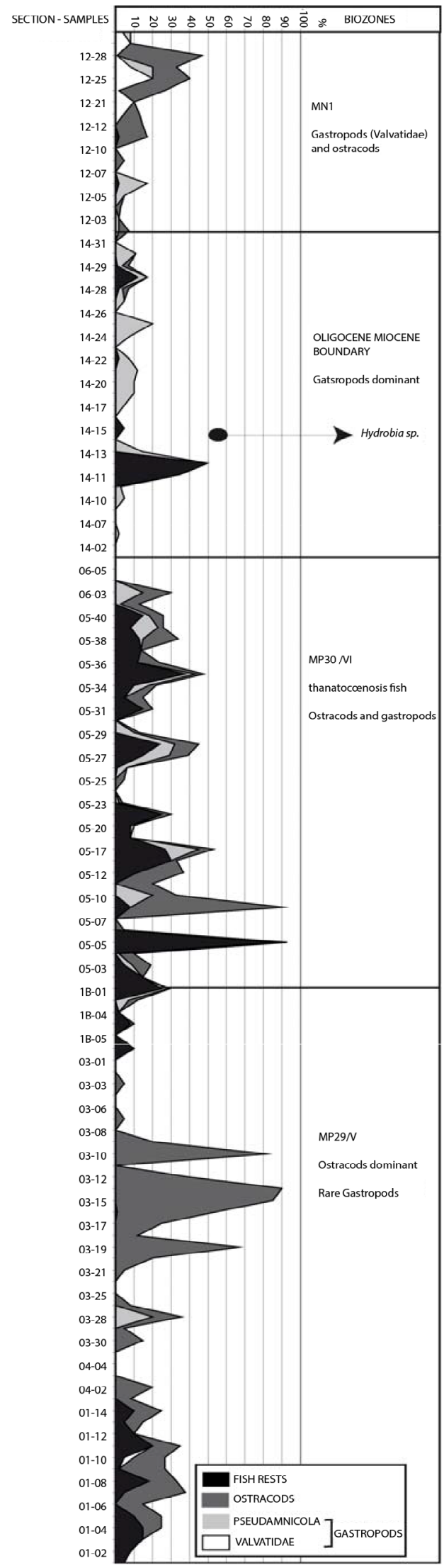

Fig. 6. Distribution of ostracods, fish teeth and gastropods in the Créchy quarry.

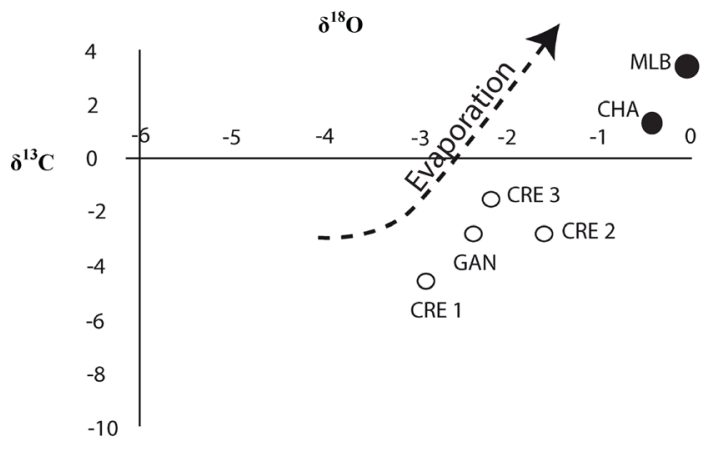

Fig. 7. Position of the studied stromatolites in a $\delta^{18} \mathrm{O}-\delta^{13} \mathrm{C}$ space. The Aquitanian samples (Chavroches, Montaigu-le-Blin, black points) seem to indicate different environments with an overall increase in evaporation.

have high positive $\delta^{13} \mathrm{C}$ values $(1.3 ; 3.3)$. The $\delta^{18} \mathrm{O}$ values increase with increasing evaporation while the photosynthetic activity associated with water evaporation also leads to increase in the $\delta^{13} \mathrm{C}$ values of the precipitated carbonate (Casanova and Hillaire-Marcel, 1992, 1993; Andrews et al., 1993, 1997; Arenas et al., 1993, 1997; Zamarreño et al., 1997). As these stromatolites are well dated by sedimentary deposits, we can observe a general trend in the lake with a gradual increase of water evaporation associated with higher photosynthetic activity (Fig. 7).

\subsection{Detailed isotopic study of the Créchy stromatolites (CRE1)}

$\delta^{18} \mathrm{O}$ and $\delta^{13} \mathrm{C}$ variations in stromatolites primarily recorded changes in the environmental hydrological parameters throughout their growth (Casanova and Hillaire-Marcel, 1992, 1993; Andrews et al., 1993, 1997; Arenas et al., 1993, 1997; Zamarreño et al., 1997). Stromatolite samples have negative $\delta^{13} \mathrm{C}$ and $\delta^{18} \mathrm{O}$ values $\left(-6.5<\delta^{13} \mathrm{C}<-2.3\right.$ and $-5.1<\delta^{18} \mathrm{O}<-1.6 ; \mathrm{n}=42$, Tab. 4; Fig. 8).

Stromatolites from Créchy (CRE-1) show a positive correlation between $\delta^{18} \mathrm{O}$ and $\delta^{13} \mathrm{C}$ values ( $r=0.75$; Fig. 8), except for samples 24 and 27. The covariance between the $\delta^{18} \mathrm{O}$ and $\delta^{13} \mathrm{C}$ values is ascribable to the isotopic evolution of the water mass and indicates rather stable hydrological conditions (Talbot and Kelts, 1990), i.e. a closed lake where primary production is influenced by periods of either water dilution or concentration. This suggests that during the growth of stromatolites, the water of the lake had probably led to establishing an isotopic equilibrium between atmospheric $\mathrm{CO}_{2}$ and the dissolved inorganic carbon (DIC) enhanced by photosynthetic activity. This process involves a ${ }^{13} \mathrm{C}$ enrichment of the water DIC due to the preferential use of the ${ }^{12} \mathrm{C}$ by the microbial community during photosynthetic activity (Rau, 1978; Herczeg and Faifbanks, 1987; Merz, 1992; Casanova and Hillaire-Marcel, 1993). Two periods are characterized by uncorrelated $\delta^{18} \mathrm{O}$ (more negative) and $\delta^{13} \mathrm{C}$ values (less negative) as revealed by samples 24 and 27 (Fig. 8). They indicate disturbances that affected the lake hydrology during the stromatolite growth. These disturbances could have various origins, such as a northward opening of the basin or a local 
Table 3. Stable isotope data for stromatolites and nodules sampled at Créchy (CRE), Montaigu-le-Blin (MLB), Chavroches (CHA) and Gannat (GAN).

\begin{tabular}{|c|c|c|c|c|c|c|c|}
\hline Age & Biozone & Stromatolite & $\delta^{18} \mathrm{O}_{\mathrm{PDB}}$ & $\delta^{13} \mathrm{C}_{\mathrm{PDB}}$ & Nodules & $\delta^{18} \mathrm{O}_{\mathrm{PDB}}$ & $\delta^{13} C_{\mathrm{PDB}}$ \\
\hline Aquitanian & MN2 & $\mathrm{CHA}$ & -0.4 & 1.3 & (4)-MLB & -4.5 & -9.1 \\
\hline \multirow[t]{2}{*}{ Chattian } & \multirow[t]{2}{*}{ MP30 } & GAN & -2.4 & -3.4 & (2)-CRE & -4.5 & -5.4 \\
\hline & & CRE (2) & -1.6 & -2.7 & (1)-CRE & -4.3 & -4.1 \\
\hline
\end{tabular}

Table 4. $\delta^{13} \mathrm{C}$ and $\delta^{18} \mathrm{O}$ values of the laminations sampled in the Créchy stromatolite (CRE 1).

\begin{tabular}{|c|c|c|c|c|c|c|c|c|}
\hline Sample & $\delta^{13} \mathrm{C}_{\mathrm{PDB}}$ & $\delta^{18} \mathrm{O}_{\mathrm{PDB}}$ & Sample & $\delta^{13} \mathrm{C}_{\mathrm{PDB}}$ & $\delta^{18} \mathrm{O}_{\mathrm{PDB}}$ & Sample & $\delta^{13} \mathrm{C}_{\mathrm{PDB}}$ & $\delta^{18} \mathrm{O}_{\mathrm{PDB}}$ \\
\hline 2 & -5.10 & -3.9 & 16 & -4.43 & -2.9 & 30 & -3.56 & -2.0 \\
\hline 4 & -4.39 & -2.8 & 18 & -4.44 & -2.7 & 32 & -6.54 & -5.1 \\
\hline 5 & -5.20 & -3.8 & 19 & -4.42 & -2.7 & 33 & -5.11 & -4.0 \\
\hline 8 & -4.06 & -2.3 & 22 & -4.10 & -3.1 & 36 & -4.41 & -2.6 \\
\hline 9 & -3.70 & -1.6 & 23 & -3.70 & -2.3 & 37 & -2.90 & -2.4 \\
\hline 10 & -4.63 & -2.7 & 24 & -3.17 & -3.2 & 38 & -2.52 & -1.8 \\
\hline 11 & -4.59 & -3.6 & 25 & -3.86 & -2.0 & 39 & -3.73 & -2.1 \\
\hline 12 & -5.10 & -3.2 & 26 & -3.57 & -2.3 & 40 & -3.38 & -2.3 \\
\hline
\end{tabular}

river input. Lastly, it can be seen that the least negative $\delta^{18} \mathrm{O}$ values are invariably located at the "surface" levels present in the stromatolite. Studying these surface levels in thin section and by cathodoluminescence shows that they are affected by dissolution gulfs associated with early diagenesis. They are related to halts in the algal growth. The isotopic record is thus most likely related to an alternation of humid and dry periods changes recorded in the stromatolite structure. Observed isotopic patterns also highlight the discontinuous growth of the stromatolite as well as the gradual increasing rate of evaporation of the lake. The general trend of the isotopic signal is interpreted as a global drying of the area through time (Casanova and Hillaire-Marcel, 1992, 1993; Arenas et al., 1993, 1997; Andrews et al., 1993, 1997; Zamarreño et al., 1997). As all the studied stromatolites recorded these periods of early diagenesis only at their surface levels, this observation allows the comparison of the average $\delta^{13} \mathrm{C}$ and $\delta^{18} \mathrm{O}$ values between the various stromatolites.

\subsection{Results for the Limagne fish teeth}

If it is postulated that the elevation of the Chattian and Aquitanian lakes were close to sea level (Briot et al., 2001), and applying the Bowen and Wilkinson (2002) equation to the isotopic results (Tab. 5), we obtain a $\delta^{18} \mathrm{O}$ value of the lake water ranging from -5 to $0 \%$ (VSMOW). We emphasize that this value is only an approximation and does not take into account the altitudinal variations of the paleo-landscape. Those equations applied to a fossil lake cannot provide water temperatures but rather their potential variations through time. Accordingly, the isotopic record is interpreted in terms of positive or negative offsets relative to an arbitrary and constant water $\delta^{18} \mathrm{O}$ value $(-3 \%)$ during the periods of aridity. The $\delta^{18} \mathrm{O}$ value of the lake water was controlled by its hydrological balance (drainage, precipitation, evaporation), although variations through time most likely resulted from changes in either air relative humidity, air temperature and wind velocity. Sedimentological analysis contributed to put limits on these uncertainties; for example, tenches live in an eutrophic medium characterized by clayey deposits and lacustrine limestones, which is an environment associated with arid climates, whereas stromatolites of the Limagne graben grew under rather wet conditions. Lacustrine limestones could have thus precipitated in the higher part of the water column due to the intense phytoplanktonic activity during periods of aridity. Samples of those limestones (Tab. 5) were selected in order to compare their $\delta^{18} \mathrm{O}$ values with those obtained from the fish teeth supposedly related to the same period of aridity (Tab. 6). The results depend on whether the sample corresponds to a single or a mixed layer, with the calculated temperature offsets varying between $-4{ }^{\circ} \mathrm{C}$ and $+2{ }^{\circ} \mathrm{C}$ (Tab. 6). 
A

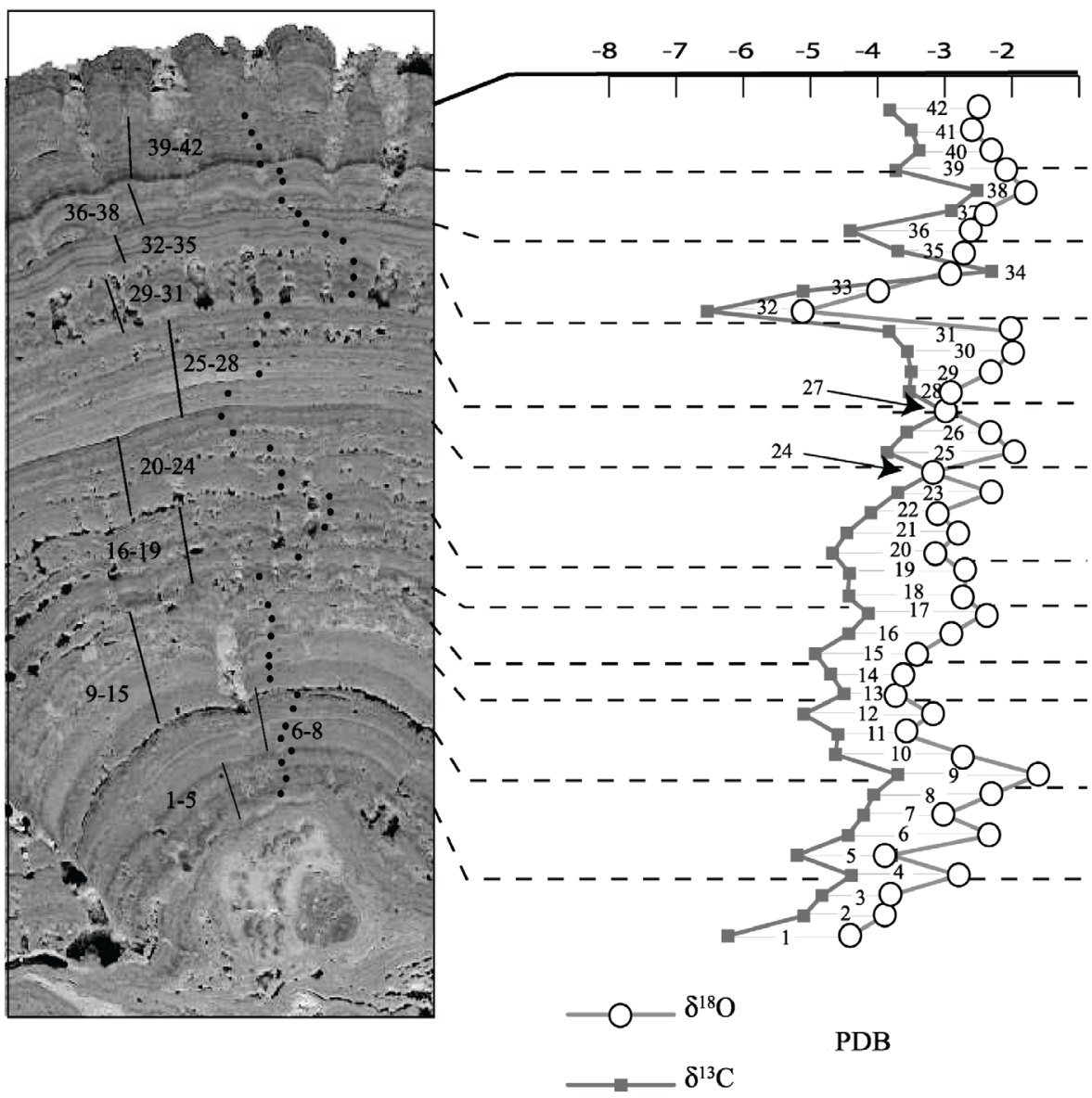

Fig. 8. A. Section of a stromatolite (CRE $1-10 \mathrm{~cm}$ high) showing the position of the sampled laminations. B. $\delta^{18} \mathrm{O}$ and $\delta^{13} \mathrm{C}$ values of the stromatolite rings.

These results show that the temperature variations between the Chattian and the Aquitanian recorded by the fish teeth are related to a weak climatic warming during the Aquitanian period.

\section{Climate evolution around the Oligocene/ Miocene boundary}

The Créchy quarry shows a great variety of rodents preserved in the Late Oligocene beds, but also registers the Oligocene/Miocene transition with a drastic reduction of the fauna content and diversity at the beginning of the Neogene (Hugueney et al., 2003). The basal Miocene impoverished faunas are dominated by eomyids and glirids and furthermore locally, zapodids. Later, the richness in species is greater as observed in Montaigu-le-Blin, which yielded an Early Miocene (MN2a) fauna characterized by 18 families and 33 species, but only 11 rodents. The faunal community indicates a more open tropical landscape. No younger fauna have been observed in the Limagne graben. Although episodes of appearance and disappearance took place in the Limagne area during the Late Oligocene (MP29-30), the most drastic event took place at the MP30/MN1 boundary Among the persistent lineages, new and more derived species developed at the Miocene base (Hugueney, 1997):

- at the family level, the entire Theridomyidae family, endemic to the European Late Eocene and Oligocene, disappeared;

- at the genus level, Cainotherium became the unique representative of the Cainotheriidae family, and Amphiperatherium of the Didelphidae family and Creodont Hyaenodon while the Artiodactyls Microbunodon and Anthracotherium disappeared. Neither the Eomyid Eomys nor the Cricetid Adelomyarion, Glirid Gliravus, and Castorid Rhizospalax crossed this boundary;

- at the species level, all the Oligocene species of Plesiosminthus disappeared and a single species, $P$. myarion appeared.

Legendre $(1987,1989)$ demonstrated that local extinctions in mammal faunas can be correlated with successive temperature decreases and that the more noticeable effect of a temperature drop is a decrease in the number of species 
Table 5. Stable isotope data for lacustrine limestones at Créchy and Montaigu-le-Blin.

\begin{tabular}{|c|c|c|c|c|}
\hline Age & Biozone & Nodules & $\delta^{18} \mathrm{O}_{\mathrm{PDB}}$ & $\delta^{13} \mathrm{C}_{\mathrm{PDB}}$ \\
\hline $\begin{array}{l}\text { Chattian/ } \\
\text { Aquitanian boundary }\end{array}$ & MP30/MN1 & (3)-CRE & -5.1 & -4.5 \\
\hline Chattian & MP30 & $\begin{array}{l}\text { (2)-CRE } \\
\text { (1)-CRE }\end{array}$ & $\begin{array}{l}-4.5 \\
-4.3\end{array}$ & $\begin{array}{l}-5.4 \\
-4.1\end{array}$ \\
\hline
\end{tabular}

Table 6. Stable isotope data for fish teeth at Créchy and Montaigu-le-Blin. The calculated temperature offsets were based on the value given by the preceding layers for a constant water $\delta^{18} \mathrm{O}$ value. Ref: starting reference level for the calculated temperature variations.

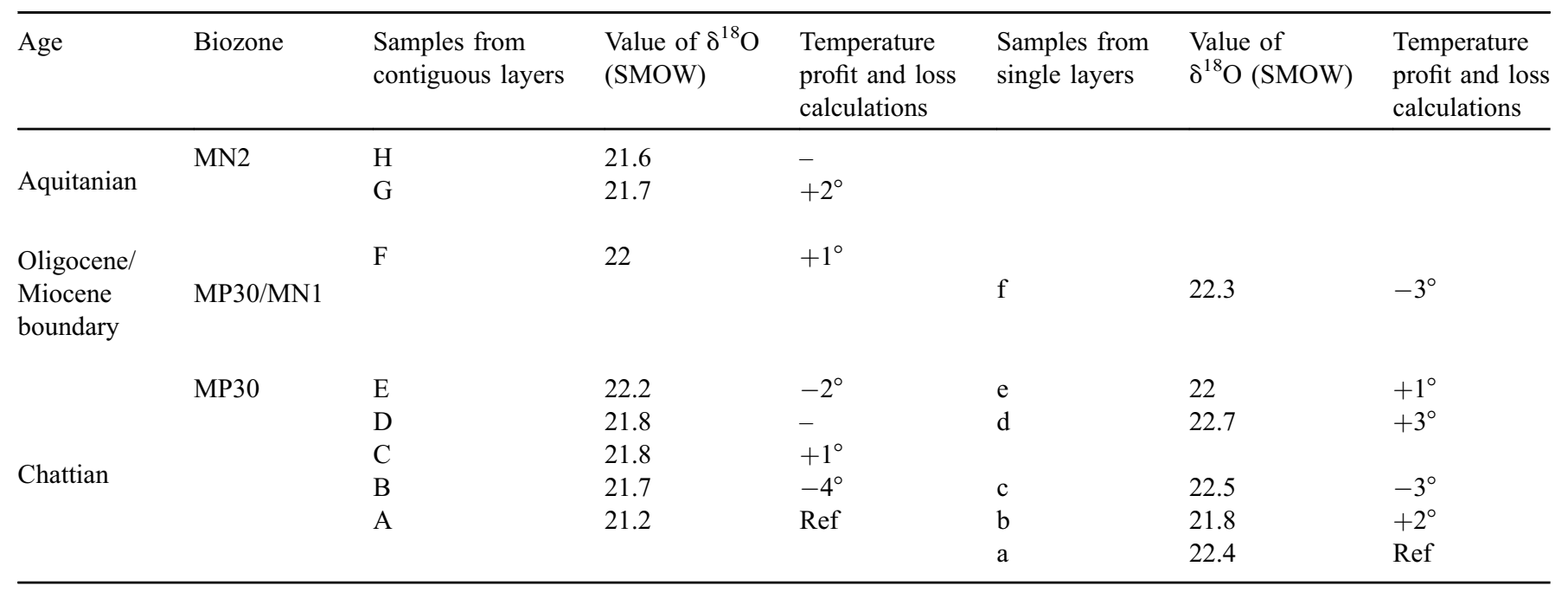

weighing less than $500 \mathrm{~g}$, which is the case for most of the Oligocene rodents. In this case, the change between the Late Oligocene and earliest Miocene faunas could be related to one or more successive climatic changes associated to enhanced seasonality (Hugueney, 1984; Comte, 2000; Becker et al., 2002).

The most comprehensive studies of the Chattian/Aquitanian floras and microfloras and their relationships to paleoclimates were mostly carried out on the western border of the Mediterranean Sea (Rhone Valley, Provence, Languedoc Roussillon, Catalonia, Portugal). The occurrence of some species (Prosopis) in the Provence area, the Swiss Molasse (Berger, 1990) and the Northern German Tertiary (Utescher, 2000) may indicate increasing climatic aridity during the Late Oligocene and Early Miocene (Guinet, 1984). Regression of angiosperms and the correlative development of Pinaceae and herbaceous plants reflect a dry period before the return of the Aquitanian-Burdigalian thermophitic floras (Chateauneuf, 1972; Chateauneuf and Nury, 1995; Bessedik, 1985; Pais, 1986).

The results obtained from the present study enable to outline the modality of the climatic evolution through the Oligocene/Miocene boundary in the Limagne graben. The sedimentary analysis of the late Oligocene deposits records an increase in palustrine indicators (mudcracks, root traces), reflecting a retreat of the shoreline. The lake water changed from fresh to brackish during the Chattian (Hugueney et al., 2003) as testified by the presence of specific gastropods (Hydrobia sp.) and flamingo nests (Paleolodus ambiguus). This period is also characterized by the development of thanatocœnoses of tenches preserved in the argillaceous beds of the end of the Oligocene.

Throughout the Oligo-Miocene boundary, the lacustrine faunal associations show a general evolution from brackish to fresh water (Tab. 7), as indicated by the appearance of freshwater ostracods and gastropods, a major development of caddisflies, and the disappearance of brackish-water gastropods (Hugueney et al., 1999; Hugueney et al., 2003).

Furthermore, the stable isotope compositions of stromatolites indicate that evaporation increased gradually toward the Oligocene/Miocene boundary.

The pollen data confirm this trend of increasing aridity furthermore revealing a cooling stage at the Oligocene/ Miocene transition. These cool conditions were first highlighted by Gorin (1975), based on the presence of Pinaceae-rich pollen assemblages. The increasing aridity associated with a cooler climate may have led to the well-documented mammal impoverishment (Hugueney, 1984; Legendre, 1987, 1989; Comte, 2000; Becker et al., 2002)

A wetter climate prevailed during the lower part of the Aquitanian (MN1) followed by a gradual increase in temperature toward the upper part of the Aquitanian (MN2). 
Table 7. Summary of climatic and environmental variations around the Oligocene/Miocene boundary determined from the sedimentology and lacustrine faunal and vegetal associations in the Limagne basin.

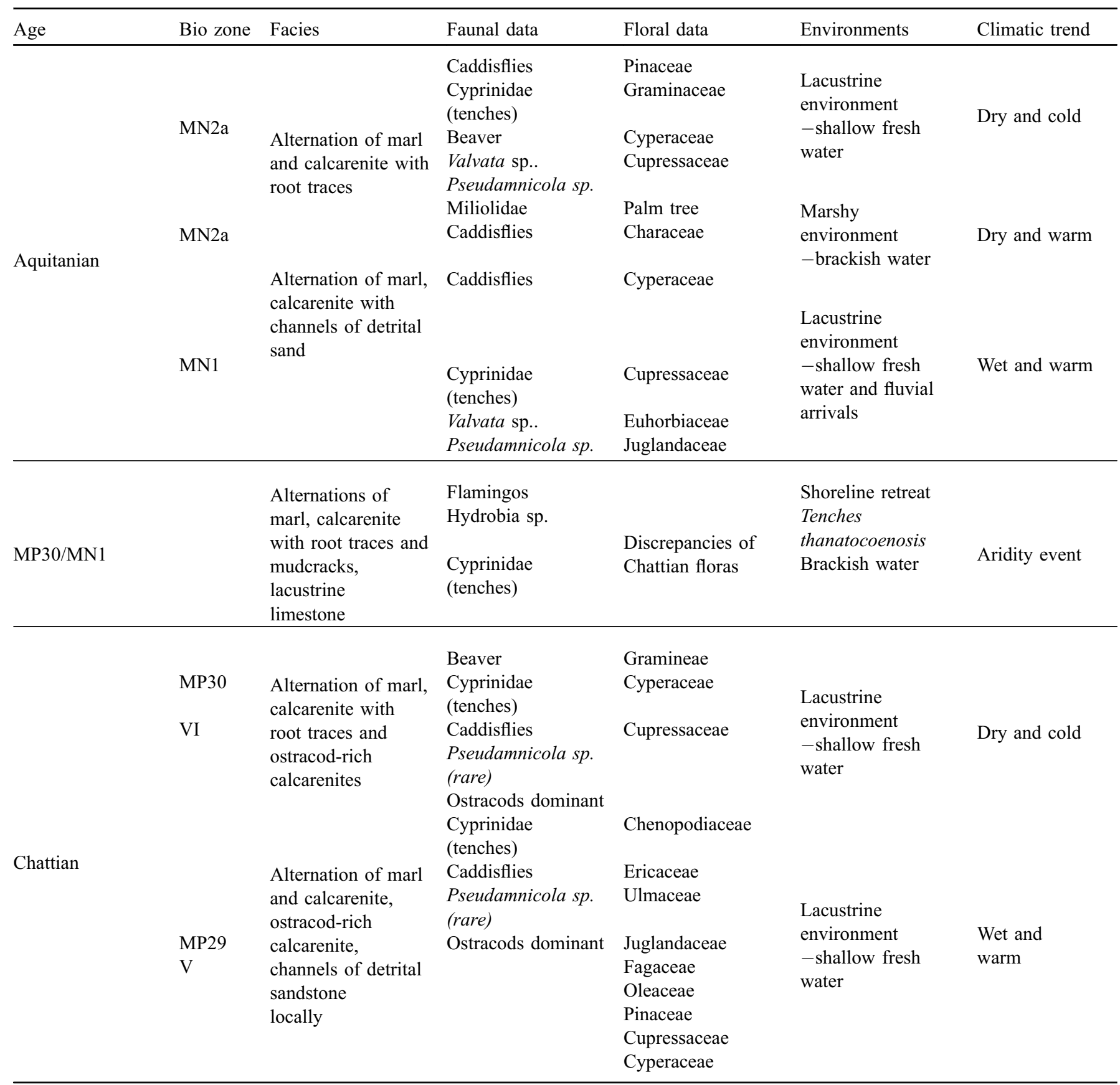

A cooler climate prevailing during the lower part of the Aquitanian is supported by the presence of Pinaceae-rich pollen assemblages (Gorin, 1975) and by the high fish tooth $\delta^{18}$ O values measured throughout the Chattian/Aquitanian boundary.

Our study confirms that the global climate evolution around the Oligocene/Miocene boundary involved several successive temperature changes as already suggested by Hugueney (1984), Comte (2000) and Becker et al. (2002), along with a general trend of increasing aridity that settled during the Aquitanian (Tab. 7).
Acknowledgements. We would like to thank J. Gaudant, A. Genter, P. Rossi, P. Jezequel, P. Lozouet, P. Maestrati, P. Freytet, B. Vincent and P. Skipwith, plus the Lasalle Beauvais Institute and MNHN Geology Laboratory for their help and support; and a special thanks to Marguerite Hugueney for her help. This study received financial support from the Conseil Général of the Allier Department, the COPGEN project, and the "Carte géologique de la France" programme. We would also like to thank Vicat, SATMA and Chaux d'Auvergne for permission to access their quarries. 


\section{References}

Anderson TF, Arthur MA. 1983. Stable isotopes of oxygen and carbon and their application to sedimentologic and paleoenvironmental problems. In: Arthur MA, Anderson TF, Kaplan IF, Veizer J, Land LS, eds. Stable Isotopes in Sedimentary Geology. SEPM Short Course 10: 1-151.

Andrews JE, Riding R, Dennis PF. 1993. Stable isotopic composition of recent freshwater cyanobacterial carbonates from the British Isles: local and regional environmental controls. Sedimentology 40: 303-314.

Andrews JE, Riding R, Dennis PF. 1997. The stable isotopic record of environmental and climatic signals in modern terrestrial microbial carbonates from Europe. Palaeogeogr Palaeoclimatol Palaeoecol 129: 171-189.

Arenas C, Pardo G, Casanova J. 1993. Bacterial stromatolites in lacustrine Miocene deposits of the Ebro Basin (Aragón, Spain). In: Barattolo F, De Castro P, Parente M, eds. Studies on fossil benthic algae. Boll Soc Paleont Ital Spec Vol. 1, Modena: Mucchi Editore, pp. 9-22.

Arenas C, Casanova J, Pardo G. 1997. Stable isotope characterization of the Miocene lacustrine systems of Los Monegros (Ebro basin, Spain): palaeogeographic and palaeoclimatic implications? Palaeogeogr Palaeoclimatol Palaeoecol 128: 133-155.

Becker D, Picot L, Berger JP. 2002. Stable isotopes of charophytes gyrogonites: example from the Brochene Fluch section (Late Oligocene-Early Miocene, Switzerland). Geobios 35: 89-97.

Berger J-P. 1990. Floral changes in the Molasse of Western Switzerland (Oligo-Miocene): paleoclimatic implications. Symposium paleofloristic and paleoclimatic changes in the cretaceous and tertiary, Prague, Abstract Volume, pp. 189-194.

Berger J-P, Reichenbacher B, Becker D, Grimm M, Grimm K, Picot $\mathrm{L}$, et al. 2005. Eocene-Pliocene time scale and stratigraphy of the Upper Rhine Graben (URG) and the Swiss Molasse Basin (SMB). Int J Earth Sci 94: 711-731. Available from http://dx.doi.org/ 10.1007/s00531-005-0479-y.

Berggren WA, Kent DV, Swisher CC, Aubry MP. 1995. A revised Cenozoic Geochronology and Chronostratigraphy. In: Berggren WA, William A, eds. Geochronology, time scales and global stratigraphic correlations: a unified temporal framework for an historical geology. SEPM, Spec 54, 392 p.

Bessedik M. 1985. Reconstitution des environnements miocènes des régions Nord-Ouest méditerranéennes à partir de la palynologie. $\mathrm{PhD}$, France: Languedoc University, $162 \mathrm{p}$.

Bout P, Frechen J, Lippolt MJ. 1966. Datations stratigraphiques et radiochronologiques de quelques coulées basaltiques de Limagne. Rev d'Auvergne 80(4): 207-231.

Bowen GJ, Wilkinson B. 2002. Spatial distribution of $\delta^{18} \mathrm{O}$ in meteoric precipitation. Geology 30(4): 315-318.

Briot D, Poidevin J-L, Hugueney M. 2001. Apports de l'étude isotopique $\mathrm{Sr}$ et $\mathrm{Nd}$ des sédiments cénozoïques de Limagne à la compréhension $\mathrm{du}$ fonctionnement $\mathrm{du}$ rift du Massif Central français. Bull Soc géol Fr 172: 17-24.

Casanova J, Hillaire-Marcel C. 1992. Late Holocene hydrological history of Lake Tanganyika, East Africa, from isotopic data on fossil stromatolites. Palaeogeogr Palaeoclimatol Palaeoecol 91: 35-48.

Casanova J, Hillaire-Marcel C. 1993. Carbon and oxygen isotopes in African lacustrine stromatolites: palaeohydrological interpretation. In: Swart PK, Lohmann KC, McKenzie J, Savin S, eds. Climate change in continental isotopic records. Geophys. Monogr. 78. Washington D.C., USA: Amer Geophys Union, pp. 123-133.
Cavelier C, Pomerol C. 1983. Échelle de corrélation stratigraphique du Paléogène. Stratotypes, étages standards, biozones, chimiozones et anomalies magnétiques. Géol Fr 3: 261-262.

Chateauneuf JJ. 1972. Étude palynologique de l'Aquitanien de la coupe de Carry-le-Rouet (Bouches-du-Rhône, France). Bull Bur Rech Geol Min, $2^{\mathrm{e}}$ série, 4: 59-65.

Chateauneuf JJ, Nury D. 1995. La flore de l'Oligocène de Provence méridionale: implications stratigraphiques, environnementales et climatologiques. Géol Fr 2: 43-55.

Comte B. 2000. Rythme et modalités de l'évolution chez les rongeurs à la fin de l'Oligocène, leurs relations avec les changements de l'environnement. Palaeovertebrata 29(2-4): 83-360.

Coplen TB, Kendall C, Hopple J. 1983. Comparison of stable isotope reference samples. Nature 302: 236-238.

Crowson RA, Showers W-J, Wright EK, Hoering TC. 1991. Preparation of phosphate samples for oxygen isotope analysis. Anal Chem 63: 2397-2400.

Dèzes P, Schmid SM, Ziegler PA. 2004. Evolution of the European Cenozoic Rift system: interaction of the Alpine and Pyrenean orogens with their foreland lithosphere. Tectonophysics 389: 1-33.

Donsimoni M. 1975. Étude des calcaires concrétionnés lacustres de l'Oligocène supérieur et de l'Aquitanien du bassin de Limagne (Massif Central, France). PhD, Paris VI (France), 197 p.

Donsimoni M, Giot D. 1977. Les calcaires concrétionnés lacustres de l'Oligocène supérieur et de l'Aquitanien de Limagne (Massif Central). Bull Bur Rech Geol Min (2), sec 1(2): 131-169.

Engesser B, Mödden C. 1997. A new version of the biozonation of the lower freshwater molasse (Oligocene and Agenian) of Switzerland and Savoy on the basis of fossils mammals. In: Aguilar JP, Legendre S, Michaux J, eds. BiochroM'97 Congress. Mem. EPHE, Montpellier Institute, 21: 475-499.

Escarguel G, Aguilar J-P. 1997. Les éomyidés Pseudotheridomys et Ligerimys (Rodentia, Mammalia) du Miocène inférieur du Sud de la France. Évolution et biostratigraphie. Palaeollfographica, A 247 (1-4): 25-58.

Fahlbusch V, Heissig K. 1987. Rodents at the Oligocene /Miocene boundary near Rottenbuch (Southern Bavaria). Münchner Geowissenschaftlichen Abhandlungen, (A) 10: 85-92.

Freytet P. 2000. Distribution and palaeoecology of non-marine algae and stromatolites: II, the Limagne of Allier Oligo-Miocène lake (central France). Ann Paléontol (Vert-Invert) 86: 3-57.

Ginsburg L, Arnaud M, Lary C, Monleau C. 1998. Le Miocène du bassin de Vence (Alpes Maritimes, France): stratigraphie et paléogéographie. Geodiversitas 20(2): 229-238.

Giot D, Dadet P, Clozier L, Fleury R. 1979. Carte géol. Fr., 1/50000, Vichy. Orléans: BRGM, pp. XXVI-29.

Gorin G. 1975. Étude palynostratigraphique des sédiments paléogènes de la Grande Limagne (Massif Central). Bull Bur Rech Géol Min, $2^{\mathrm{e}}$ série, sec. 1(3): 147-181.

Grolier J, Tchimichkian G. 1963. Connaissances nouvelles sur la géologie du socle de la Limagne, d'après les sondages de la Régie Autonome des Pétroles. Bull Soc géol Fr 5(7): 930-937.

Guinet P, Bessedik M. 1984. The early Aquitanian and upper Langhian-Lower Serravalian environments in the northwestern mediterranean region. Paléobiologie continentale, Montpellier, XIV(2): 43-55.

Guillot L. 1991. Recherches géologiques sur le bassin de Couleuvre (03). Rev Sc Bourbonnais, 34-43.

Harland WB, Cox AV, Llewellyn PG, Craig LE, Smith AG, Walters R. 1982. A geological time scale. Cambridge: Cambridge University Press, $131 \mathrm{p}$.

Herczeg AL, Faifbanks RG. 1987. Anomalous carbon isotope fractionation between atmospheric $\mathrm{CO}_{2}$ and dissolved inorganic 
carbon induced by intense photosynthesis. Geochim Cosmochim Acta 51: 895-899.

Hochuli PA. 1979. The Palaeoclimatic evolution in the Late Palaeogene and the Early Neogene. Ann Géol Pays Hellén, Tome Hors série, fasc. II: 515-523.

Hochuli PA. 1984. Correlation of middle and late tertiary Sporomorph assemblages. Paléobiologie continentale, Montpellier, XIV(2): 301-314.

Hugueney M. 1984. Évolution du paléoenvironnement dans le tertiaire de Limagne (Massif Central, France) à partir des faunes de mammifères. Geobios, Lyon, Mém. Spécial, 8: 385-391.

Hugueney M. 1997. Biochronologie mammalienne dans le Paléogène et le Miocène inférieur du Centre de la France: synthèse réactualisée. In: Aguilar JP, Legendre S, Michaux J, eds. BiochroM'97 Congress. Mem. EPHE, Montpellier Institute, 21: 417-430.

Hugueney M, Truc G. 1976. Corrélations stratigraphiques et paléogéographie des formations marines et continentales à la limite Oligocène-Miocène dans le S E de la France. Geobios 9(3): 363-365.

Hugueney M, Poidevin J-L, Bodergat AM, Caron J-B, Guerin C. 1999. Des mammifères de l'Aquitanien inférieur à La RocheBlanche-Gergovie (Puy-de-Dôme, France), révélateurs de l'activité post-oligocène du rift en Limagne de Clermont. C R Acad Sci 328: 847-852.

Hugueney M, Berthet D, Bodergat AM, Escuillié F, Mourer-Chauviré C, Wattinne A. 2003. La limite Oligo-Miocène en Limagne: changements fauniques chez les mammifères, oiseaux et ostracodes des différents niveaux de Billy-Créchy (Allier, France). Geobios 36: 719-731.

Jeambrun M, Giot D, Bouiller R, Baudry D, Camus G, Guyonnaud G, et al. 1973. Carte géol. Fr., 1/50000, Clermont-Ferrand. Orléans : BRGM, pp. XXVI-31.

Jung J. 1946. Géologie de l'Auvergne et de ses confins bourbonnais et limousins. Mém Expl Carte géol France, 372 p.

Kolodny Y, Luz B, Navon O. 1983. Oxygen isotope variations in phosphate of biogenic apatites, I. Fish bone apatite-rechecking the rules of the games. Earth Planet Sci Lett 64: 398-404.

Lécuyer C, Grandjean P, O’Neil J-R, Carpetta H, Martineau F. 1993. Thermal excursions in the ocean at the Cretaceous-Tertiary boundary (northern Morocco): The $\delta^{18} \mathrm{O}$ record of phosphatic fish debris. Palaeogeogr Palaeoclimatol Palaeoecol 105: 235-243.

Lécuyer C, Grandjean P, Barrat JA, Nolvak J, Emig C, Paris F, et al. 1998. $\delta^{18} \mathrm{O}$ and REE contents of phosphatic brachiopods: A comparison between modern and lower Paleozoic populations. Geochim Cosmochim Acta 62(14): 2429-2436.

Lécuyer C, Amiot R, Touzeau A, Trotter J. 2013. Calibration of the phosphate $\delta^{18} \mathrm{O}$ paleothermometer with carbonate-water oxygen isotope fractionation equations. Chem Geol 347: 217-226.

Legendre S. 1987. Mammalian faunas as paleotemperature indicators: concordance between oceanic and terrestrial paleontological evidence. Evolutionary Theory 8: 77-86.

Legendre S. 1989. Les communautés de mammifères du Paléogène d'Europe occidentale; structure, milieux et évolution. Mÿnchner Geowissenschaftlichen Abhandlungen, A 16: 1-110.

Massoubre M. 1986. Approche géologique de la Limagne bourbonnaise. Mém Géol IGAL 38, 95 p.

Maury RC, Varet J. 1980. Le volcanisme tertiaire et quaternaire de France. 26th Int. Geol. Congr. (Paris), BRGM 3, 142 p.

Merle O, Michon L, Camus G, De Goër A. 1998. L'extension oligocène sur la transversale septentrionale du rift du Massif Central. Bull Soc géol Fr 169(5): 615-626.
Merz MUE. 1992. The biology of carbonate precipitation by cyanobacteria. Facies 26: 81-102.

Michon L. 2000. Dynamique de l'extension continentale-Application au Rift Ouest Européen par l'étude de la province du Massif Central. PhD., Blaise Pascal University, 266 p.

Morange A, Heritier F, Villemin J. 1971. Contribution de l'exploration pétrolière à la connaissance structurale et sédimentaire de la Limagne dans le Massif Central. In: Géologie, géomorphologie et structure profonde du Massif Central français. Symp J Jung, Clermont-Ferrand, 295-308.

Neubauer T, Harzhauser M, Kroh A, Georgopoulou E, Mandic O. 2015. Agastropod-based biogeographic scheme for the European Neogene freshwater systems. Earth-Science Reviews 143: 98-116.

Nury D. 1988. L'Oligocène de Provence méridionale. Documents $d u$ $B R G M 163,411 \mathrm{p}$.

Nury D, Villeneuve M, Arlhac P, Gärtner A, Linnemann U, Châteauneuf JJ, et al. 2016. New insights on the MarseilleAubagne Oligocene basins (France). Boletín Geológico y Minero 127(2/3): 483-498.

Odin GS. 1994. Geological time scale. C R Acad Sci 318(2): 59-71.

Odin GS, Montanari A, Coccioni R. 1997. Chronostratigraphy of Miocene stages: a proposal for the definition of precise boundaries. In: Montanari A, Odin GS, Coccioni R, eds. Miocene stratigraphy: an integrated approach. Elsevier Science, pp. 597-629.

O’Neil JR, Roe L, Reinhard E, Blake RE. 1994. A rapid and precise method of oxygen isotope analysis of biogenic phosphates. Israel $J$ Earth Sci 43: 203-212.

Pais J. 1986. Évolution de la végétation et du climat pendant le Miocène au Portugal. Ciências da Terra (UNL), Lisboa, Portugal, 8: 179-191.

Picot L. 2002. Le Paléogène des synclinaux du Jura et de la bordure sud-rhénane : paléontologie (ostracodes), paléoécologie, biostratigraphie et paléogéographie. GeoFocus, Fribourg (Switzerland), 5: $1-240$.

Popov SV, Rögl F, Rozanov AY, Steininger FF, Shcherba IG, Kovac M. 2004. Lithological-Paleogeographic maps of Paratethys. 10 Maps. Late Eocene to Pliocene. Cour Forsch Senckenberg 250: 1-46.

Rau G. 1978. Carbon-13 depletion in a subalpine lake: Carbon flow implication. Science 201: 901-902.

Riveline J, Giot D, Farjanel G, Pacquet A. 1988. Mise en évidence de dépôts Eocène moyen Lutétien supérieur) à la base des formations tertiaires du bassin de Moulins (Allier, France). Implications tectoniques. C R Acad Sci 306(série II): 55-62.

Roche A, Vennin E, Bouton A, Olivier N, Wattinne A, Bundeleva I, et al. 2018. Oligo-Miocene lacustrine microbial/metazoan buildups from the Limagne Basin (French Massif Central). Palaeogeogr Palaeoclimatol Palaeoecol, Elsevier, 504, pp. 34-59.

Roques M. 1971. Structure géologique du Massif Central. In: Géologie, géomorphologie et structure profonde du Massif Central français. Symp J Jung, Clermont-Ferrand, 17-32.

Schuler M, Sittler C. 1969. Étude palynologique et écologique des séries tertiaires du bassin de Montbrison (Massif Central français). Bull Serv Carte Geol Als Lorr 22(2): 159-184.

Schuler M, Sittler C. 1976. Présence d'un grain de pollen Boehlensipollis Hohli W. KR 1962 dans les séries tertiaires de la plaine du Forez (Massif Central). Attributions stratigraphiques nouvelles de ces terrains. Sci Geol Bull, Strasbourg 29(1): 91-92.

Shemesh A, Kolodny Y, Luz B. 1988. Isotope geochemistry of oxygen and carbon in phosphate and carbonate of phosphorite francolite. Geochim Cosmochim Acta 52(11): 2565-2572.

Talbot MR, Kelts K. 1990. Paleolimnological signatures from carbon and oxygen isotopic ratios in carbonates from organic carbon-rich 
lacustrine sediments. In: Katz BJ, ed. Lacustrine Basin Exploration, Case Studies and Modern Analogs. Mém AAPG 50: 99-112.

Terry RD, Chilingar GV. 1955. Summary of "Concerning some additional aids in studying sedimentary formations" by M.S. Shvetsov. Journal of Sedimentary Petrology 25: 229-234.

Tourenq J. 1989. Les sables et argiles du bourbonnais (Massif Central, France), une formation fluvio-lacustre d'âge pliocène supérieur, étude minéralogique, sédimentologique et stratigraphique. $\mathrm{PhD}$, Paris, France: Université Paris VI, doc. BRGM 174, 333 p.

Tudge AP. 1960. A method for analysis of oxygen isotopes in orthophosphate, its use in the mesurement of palaeotemperatures. Geochim Cosmochim Acta 18: 81-93.

Utescher T. 2000. Terrestrial climate evolution in Northwest Germany over the last 25 million years. Palaios 15: 430-449.

Wattinne A. 2004. Évolution d'un environnement carbonaté lacustre à bioconstructions, en Limagne bourbonnaise (Oligo-Miocène,
Massif Central, France). PhD, Paris, France: Muséum National d'Histoire Naturelle, $280 \mathrm{p}$.

Wattinne A, Vennin E, De Wever P. 2003. Évolution d'un environnement carbonaté lacustre à stromatolithes, par l'approche paléo-écologique (carrière de Montaigu-le-Blin, bassin des Limagnes, Allier, France). Bull Soc géol Fr 174: 49-66.

Zachos J, Pagani M, Sloan L, Thomas E, Billups K. 2001. Trends, rhythms, and aberrations in global climate $65 \mathrm{Ma}$ to present. Science 292: 686-693.

Zamarreño L, Anadon P, Utrilla R. 1997. Sedimentology and isotopic composition of upper Paleocene to Eocene non-marine stromatolites, eastern Ebro basin, NE Spain. Sedimentology 44: 159-166.

Ziegler PA. 1990. Geological atlas of Western and Central Europe, second and completely revised edition. Shell International Petro. Maatschappi B.V.: Geological Society Publishing House, 239 p.

Cite this article as: Wattinne A, Lécuyer C, Vennin E, Chateauneuf J-J, Martineau F. 2018. Environmental changes around the Oligocene/ Miocene boundary in the Limagne graben, Massif Central, France, BSGF - Earth Sciences Bulletin 189: 19. 